\title{
IgE and IgG antibodies in skin allergy of the horse
}

\author{
Bettina WAGNER $^{\mathrm{a} *}$, William H. MILleR ${ }^{\mathrm{b}}$, Erin E. MorGAN ${ }^{\mathrm{a}}$, \\ Julia M. HILLEGAS ${ }^{\mathrm{a}}$, Hollis N. ERB ${ }^{\mathrm{c}}$, Wolfgang LEIBOLD ${ }^{\mathrm{d}}$, \\ Douglas F. ANTCZAK ${ }^{\mathrm{a}}$ \\ ${ }^{a}$ Baker Institute for Animal Health, College of Veterinary Medicine, Cornell University, \\ Ithaca, NY 14853, USA \\ ${ }^{\mathrm{b}}$ Department of Clinical Sciences, College of Veterinary Medicine, Cornell University, \\ Ithaca, NY 14853, USA \\ ${ }^{c}$ Department of Population Medicine and Diagnostic Sciences, College of Veterinary Medicine, \\ Cornell University, Ithaca, NY 14853, USA \\ ${ }^{\mathrm{d}}$ Institute of Immunology, University of Veterinary Medicine, 30173 Hannover, Germany
}

(Received 15 March 2006; accepted 5 June 2006)

\begin{abstract}
In horses, allergies have been characterized by clinical signs and/or intradermal (i.d.) allergen testing. Our aim was to find the first direct evidence that immunoglobulin E ( $\operatorname{IgE}$ ) mediates equine allergy. In addition, we tested the hypothesis that immediate skin reactions in horses can also be mediated by $\operatorname{IgG}$. Anti-IgE affinity columns were used to purify $\operatorname{IgE}$ from serum of one healthy horse and three horses affected with summer eczema, an allergic dermatitis which is believed to be induced by Culicoides midges. A modified Prausnitz-Küstner experiment was performed in four clinical healthy horses by i.d. injection of the purified serum IgE antibodies. The following day, Culicoides allergen was injected at the same sites. Skin reactions were not observed in response to allergen alone, and in two horses after stimulation at any previous IgE injection site. However, the other two horses showed an immediate skin reaction at the previous injection sites of IgE obtained from allergic horses. In addition, purified monoclonal antibodies to various equine immunoglobulin isotypes were injected i.d. into six healthy horses. Immediate skin reactions were observed in response to anti-IgE (6/6 horses) and anti-IgG(T) injections (5/6 horses). The specificities of both antibodies for $\operatorname{IgE}$ and $\operatorname{IgG}(\mathrm{T})$, respectively, were confirmed by enzyme linked immunosorbent assays. The results provide the first direct evidence that IgE mediates classical Type-I allergy in horses and plays a major role in the pathogenesis of summer eczema. The data also suggest that $\operatorname{IgG}(\mathrm{T})$ can bind to skin mast cells and might contribute to clinical allergy.
\end{abstract}

horse / allergy / summer eczema / IgE / IgG

\section{INTRODUCTION}

Based on clinical signs and intradermal (i.d.) skin testing, several diseases have been associated with Immunoglobulin $\mathrm{E}$ ( $\mathrm{IgE}$ ) mediated allergy in horses

*Corresponding author: bw73@cornell.edu
[19]. These include skin hypersensitivities [4, 13, 27], urticaria [17], chronic obstructive pulmonary disease (recurrent airway obstruction) [20, 24], and headshaking [17]. Epidemiological data about allergy in horses are rare. This most likely reflects the existing difficulties in precisely diagnosing the presence of allergy. 
Currently, the best allergy test available is intradermal skin testing with allergen extracts. However, this procedure requires expertise in technical performance and interpretation of the results. Thus, it is mainly performed in some larger clinics or university hospitals [14]. Because of economic, scheduling, or transportation issues, allergies in the field are often diagnosed by clinical signs only. These horses generally do not contribute to statistical analysis about the prevalence of allergy.

The most common skin hypersensitivity in horses is called "summer eczema" or "sweet itch". This is a recurrent allergic dermatitis that has been described frequently in Icelandic horses, but it also occurs in many other horse breeds, including Thoroughbreds, Arabians, Warmbloods, Draft horses, Quarter horses and ponies. Summer eczema has been found all over the world and is believed to be induced by allergens from the saliva of biting midges of Culicoides spp. [2,4,8,9,13,15]. The prevalence of the disease varies between $3-72 \%[5,10,12]$. Similar to human atopic dermatitis, summer eczema is not life-threatening, but it induces high levels of discomfort and massive scratching followed by loss of hair and severe skin irritations. Current treatments include allergen avoidance, anti-allergic medications, and immunotherapy, also known as "hypo-" or "desensitization" [3]. The current therapies reduce clinical signs but do not cure the allergic disease.

$\operatorname{IgE}$ has a natural protective function as a defense against parasites. However, IgE can also mediate pathological reactions which manifest as allergy. IgE binds to high-affinity IgE-receptors (FceRI) on mast cells. This interaction between $\operatorname{IgE}$ and the FceRI plays a key role in allergic inflammatory responses induced by mast cell degranulation. Type-I hypersensitivities are characterized by an initial contact to the allergen, resulting in activation of B-cells and production of allergen-specific
IgE antibodies. These antibodies are subsequently bound by high-affinity FceRI on cell membranes of mast cells and basophils, a process which is called "sensitization". The IgE sensitized cells can be stimulated at each successive contact with allergen, resulting in release of preformed inflammatory mediators, such as histamine, and induction of synthesis and release of leukotrienes, prostaglandins and cytokines, all of which together initiate the inflammatory response and maintain the production of allergen-specific IgE [11].

Although a role for IgE-mediated mast cell degranulation in summer eczema has been hypothesized by inducing immediate skin reactions after intradermal Culicoides allergen exposure in affected horses [2, 4, 13], the direct involvement of $\mathrm{IgE}$ has not yet been demonstrated. Our aim was to provide the first formal evidence that $\operatorname{IgE}$ mediates allergy in horses. We performed two experiments. First, we used a previously described method to purify IgE from serum [30] and performed a PrausnitzKüstner (P-K) experiment by transferring the allergic reaction to healthy animals using IgE from horses affected with summer eczema. Second, to determine the immunoglobulin isotypes which can mediate mast cell degranulation in horses, we tested monoclonal antibodies (mabs) to equine $\operatorname{IgE}$ and $\operatorname{IgG}$ isotypes for their potential to induce an immediate skin reaction in vivo.

\section{MATERIALS AND METHODS}

\subsection{Horses}

The recipient horses for the P-K experiment and for intradermal (i.d.) injection of anti-equine $\mathrm{IgE}$ or IgG mabs were clinical healthy, adult horses (10-19 years of age) from the experimental herd at the Baker Institute for Animal Health. Two geldings and four mares of different breeds (Thoroughbred, Warmblood, Quarter Horse) were used. The serum donors 
for the P-K experiment and the peripheral blood donors for the histamine release assay were adult female Icelandic horses with or without clinical signs of summer eczema. All experimental procedures were approved by the Animal Care Committee of Cornell University and were in accordance with the guidelines established by the NIH.

\subsection{Purification of IgE and IgG from serum}

$\operatorname{IgE}$ and $\operatorname{IgG}$ were purified from equine serum as previously described [30]. In brief, the purification was performed using an ÄKTA FPLC instrument (Amersham Biosciences, Piscataway, NJ, USA) and two affinity columns. First, a Protein G affinity column (HiTrap Protein G, Amersham Biosciences, Piscataway, NJ, USA) was used to deplete IgG from serum. Second, the IgG depleted serum was passed over an anti-equine IgE affinity column generated by coupling of anti-IgE134 mab to $\mathrm{CNBr}$-activated sepharose $4 \mathrm{~B}$. Both the Protein $\mathrm{G}$ and anti-IgE columns were eluted using $0.1 \mathrm{M}$ glycine $(\mathrm{pH} 3.0)$ and the eluates were subsequently neutralized in $1 \mathrm{M}$ Tris buffer $(\mathrm{pH} 8.0)$. All eluates were dialyzed against $0.9 \%$ (w/v) $\mathrm{NaCl}$ solution. The eluates obtained from the anti-IgE column were concentrated using Amicon Ultra 15 concentrators with a $30 \mathrm{kDa}$ cut-off (Millipore, Bedford, MA, USA). The purified IgG and IgE fractions were transferred passively to non-allergic horses in the $\mathrm{P}-\mathrm{K}$ experiment.

\subsection{SDS-Page and western blotting}

SDS-Page and western blotting were performed as described [28]. In brief, $7.5 \%$ SDS gels were used to separate the serum fractions obtained during purification of $\operatorname{IgE}$ and $\operatorname{IgG}$. All samples were run under non-reducing conditions. The proteins were either stained in the gel using Coomassie Brilliant Blue or blotted to PVDF membranes (Bio-Rad, Hercules, CA, USA). The membranes were incubated with the following monoclonal antibodies to equine IgG: anti-IgGa (CVS45), anti-IgGb (CVS39), anti-IgGc (CVS52), and anti-IgG(T) (CVS40) $[16,26]$. The CVS antibodies were kindly provided by Dr P. Lunn (Colorado State University, Fort Collins, CO, USA).

\subsection{Prausnitz-Küstner (P-K) experiment}

The horses used as recipients in this experiment showed no clinical signs of skin hypersensitivity over the past two summers, nor reaction to Culicoides allergen when skin testing was performed. An area at the lateral side of the neck was prepared for i.d. injection by clipping. A total of $100 \mu \mathrm{L}$ purified $\mathrm{IgE}(50 \mu \mathrm{g} / \mathrm{mL})$ and $\mathrm{IgG}$ $(300 \mu \mathrm{g} / \mathrm{mL})^{1}$ were injected i.d. to four animals. The next day, allergen (Culicoides extract; 1000 pnu/mL; Greer Laboratories, Lenoir, NC, USA) was injected at the same injection sites. Histamine $(27.5 \mu \mathrm{g} / \mathrm{mL})$

\footnotetext{
${ }^{1}$ Because of the believed role of $\operatorname{IgE}$ in allergic reactions, the $\operatorname{IgG}$ fractions were included as negative controls in the PrausnitzKüstner experiment. The purified IgG antibodies from adult horses represent the accumulated immunological experience of these animals against a wide variety of antigens, including pathogens and vaccines. In contrast to $\mathrm{IgG}$, the $\operatorname{IgE}$ antibody response is believed to be more restricted and is provoked mainly by allergens and also parasite infections. We used higher amounts of purified $\operatorname{IgG}$ than of $\operatorname{IgE}$ for intradermal injection to address the predicted variation of antibody specificities in these fractions. However, both purified fractions were polyclonal and the concentrations of antigenspecific antibodies were unknown.
} 
and saline served as positive and negative controls (both from Greer Laboratories). The skin reactivity was read after 15-20 min. The reactions were visible as wheals at the injection sites and were evaluated by inspection and palpation. A score (0-4) was recorded for the wheal sizes at each i.d. injection site and photographs of the reactions were taken. The score of 0 was always given for the saline control and the score of 4 was applied to the wheal of each histamine control. The remaining reactions were rated according to the histamine control for each recipient horse. The evaluation of skin reactivity and the scoring were performed blindly by the same person. Additional controls of the reactions were performed at 4 and $24 \mathrm{~h}$ after allergen injection.

\subsection{Monoclonal antibodies used in intradermal skin testing}

The following anti-equine immunoglobulin mabs were used in vivo for i.d. injection: anti-IgE134 and anti-IgE176 recognizing different epitopes of the IgE heavy chain [30], and the IgG-specific mabs antiIgGa (CVS45), anti-IgG(T) (CVS40), and anti-IgGb (CVS39). A total of $100 \mu \mathrm{L}$ of each antibody dilution $(50 \mu \mathrm{g} / \mathrm{mL})$ was used per injection. All monoclonal antibodies were mouse IgG1 isotypes.

\subsection{Specificity testing of mabs (ELISA)}

The mabs to equine IgE (anti-IgE134 and anti-IgE176) and the anti-IgG(T) antibody (CVS40) were tested by ELISA for their specificity for $\operatorname{IgE}$ and $\operatorname{IgG}(\mathrm{T})$, respectively. The ELISA was set up in different ways to test whether these three mabs specifically detected equine $\operatorname{IgE}$ and $\mathrm{IgG}(\mathrm{T})$ or cross-reacted with the other isotype. The coating of the plates was performed with anti-IgE176, CVS40 or poly- clonal goat anti-horse $\operatorname{IgG}(\mathrm{H}+\mathrm{L})$ in concentrations of $5 \mu \mathrm{g} / \mathrm{mL}$. IgE was purified from serum as described above and used in concentrations of $400 \mathrm{ng} / \mathrm{mL}$. IgG(T) was obtained from the serum flowthrough after passing over the protein $\mathrm{G}$ and antiIgE columns and used in a dilution of 1:200. The biotinylated antibodies antiIgE134 or CVS40 were used for detection. Afterwards, streptavidin conjugated peroxidase and substrate solution were added to the plates. All buffers, substrate solution, incubation steps and the measurement of the plates were used as described previously [30]. The $\operatorname{IgG}(\mathrm{T})$ fraction was tested in a different ELISA using all anti-IgG and anti-IgE antibodies described above. The $\operatorname{IgG}(\mathrm{T})$ fraction contained high amounts of $\operatorname{IgG}(\mathrm{T})$ as detected by the CVS40 antibody. No IgGa, IgGc or IgE and only low amounts of $\mathrm{IgGb}$ were detectable in the $\mathrm{IgG}(\mathrm{T})$ fraction (data not shown).

\subsection{Histamine release assay}

Histamine release was performed in whole blood samples. Heparinized equine peripheral blood was obtained from four Icelandic horses affected with summer eczema. The plasma was removed by two washes with phosphate buffered saline (PBS) and the cells were resuspended in release buffer $(119 \mathrm{mmol} / \mathrm{L} \mathrm{NaCl}, 5 \mathrm{mmol} / \mathrm{L}$ $\mathrm{KCl}, 0.4 \mathrm{mmol} / \mathrm{L} \mathrm{MgSO}_{4}, 25 \mathrm{mmol} / \mathrm{L}$ Pipes acid, $56 \mathrm{mmol} / \mathrm{L}$ glucose, $40 \mathrm{mmol} / \mathrm{L}$ $\mathrm{NaOH}$; and freshly added before use: $1 \mathrm{mmol} / \mathrm{L} \mathrm{CaCl}_{2}$ ). A total of $500 \mu \mathrm{L}$ of resuspended cells were used per sample. One of the samples from each horse was boiled for $5 \mathrm{~min}$ and used to determine the maximal release. The remaining samples were incubated for $1 \mathrm{~h}$ at $37^{\circ} \mathrm{C}$ in release buffer only (spontaneous release), or after adding Culicoides extract $(15 \mu \mathrm{g} / \mathrm{mL})$, or antiIgE134 or anti-IgE176 (cell culture supernatants diluted 1:2). After incubation, the cells were put on ice for $20 \mathrm{~min}$. Then, all 
samples were spun down $(700 \mathrm{~g}, 10 \mathrm{~min}$, $4{ }^{\circ} \mathrm{C}$ ) and the supernatants were collected. The radioimmunoassay to measure the histamine concentration in the supernatants was described previously in detail [29]. The evaluation was performed by setting the maximal release sample for each horse as $100 \%$. The relative histamine content in the other samples was calculated according to the corresponding maximal release. This relative evaluation allowed the comparison of samples from different animals, independent of the number of basophils and the histamine content per cell in samples from different horses.

\subsection{Statistics}

Scores were recorded for immediate skin reactivity at each reaction site. Median scores were calculated across horses for identical intradermal injections. The histamine release data (relative percentages) were presented as minimum, median, and maximal, because for several antibodies the SD was large relative to the mean. $P$-values were calculated by Wilcoxon signed-rank tests.

\section{RESULTS}

\subsection{Immunoglobulin isotype composition of purified serum IgG and IgE}

$\operatorname{IgE}$ and $\mathrm{IgG}$ from the serum of four Icelandic horses (donors) were purified. Three horses were affected with skin hypersensitivity (summer eczema) and reacted to Culicoides extract. The fourth horse was healthy and not sensitized to Culicoides. The sera were passed over a Protein $G$ column to deplete IgG antibodies (Fig. 1A). The IgG-depleted serum fraction 2 (Fig. 1A) was then applied to an anti-equine IgE Sepharose column to purify $\operatorname{IgE}$. $\operatorname{IgG}$ and $\operatorname{IgE}$ fractions 3 and 4
(Fig. 1A) were tested by ELISA and western blotting for their immunoglobulin isotype content. The IgE fractions contained IgE, small contaminations of IgM, but no IgG (data not shown). Different antibodies to $\mathrm{IgG}$ were used for detection of the IgG fractions from donor horses by western blotting (Fig. 1B). This indicated that the purified $\mathrm{IgG}$ fractions contained $\mathrm{IgGa}$, $\mathrm{IgGb}$ and $\mathrm{IgGc}$. In contrast, $\operatorname{IgG}(\mathrm{T})$ was not detectable in the $\mathrm{IgG}$ fractions.

\subsection{Intradermal transfer of an allergic reaction by IgE (Prausnitz-Küstner reaction)}

To provide direct evidence that $\operatorname{IgE}$ mediates allergic responses in the horse, $\mathrm{IgE}$ fractions from four donor horses were transferred into the skin of four clinical healthy animals (recipients). In addition to the absence of clinical signs, the four recipients were not sensitized to Culicoides. This was tested by i.d. injection of Culicoides extract alone. On day 1 , the recipients obtained purified IgG and IgE from the donor horses by i.d. injection. On the next day, an allergen (Culicoides extract) was applied at the same skin locations of the recipients. After 15-20 min, the skin reaction was evaluated and a score was applied relative to the saline (score 0 ) and histamine (score 4) controls. Allergic skin reactions were detected in two of the four healthy recipient horses after transfer of purified IgE (Fig. 2). These animals showed an immediate skin reaction after allergen injection in 4 of 6 injection sites of IgE from allergic horses (scores 2 or 3 ). No skin reactions were observed at the injection sites of IgE obtained from the control horse $(0 / 2)$. IgG fractions of the same donor horses were injected as controls in this experiment. Only one weak reaction (score 1) was observed at the IgG injection sites $(1 / 8)$. As mentioned above, the purified $\mathrm{IgG}$ used in the transfer experiment 

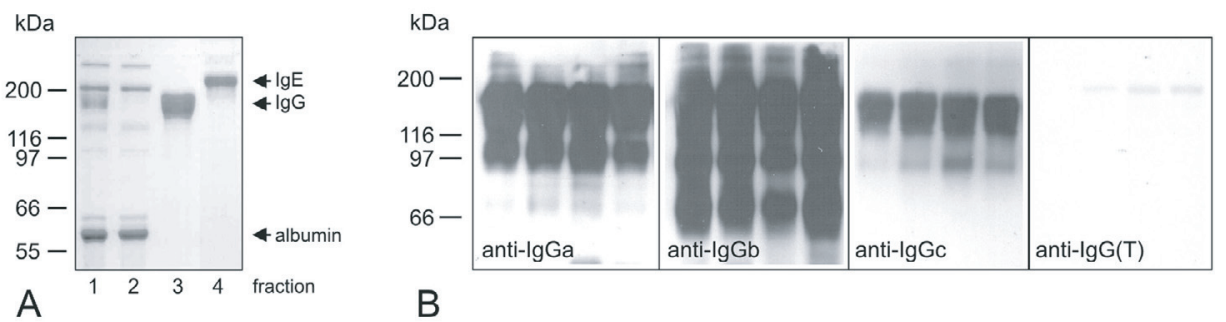

Figure 1. SDS-PAGE and western blotting of equine immunoglobulin fractions. $\operatorname{IgG}$ and $\operatorname{IgE}$ antibodies were purified from horse serum using two affinity columns, a Protein G column and an anti-equine IgE column. The fractions obtained by this procedure were separated in 7.5\% SDS-gel under non-reducing conditions. (A) The Coomassie Blue stained gel shows the serum and purified fractions of one horse: (1) serum before purification; (2) flowthrough after Protein $\mathrm{G}$ and before anti-IgE affinity purification; (3) pH 3.0 eluate from Protein G column; (4) concentrated $\mathrm{pH} 3.0$ eluate from anti-IgE column. (B) The IgG fractions (lane 3 in A) obtained from four horses were separated on $7.5 \%$ SDS-gels under non-reducing conditions and transferred to PVDF membranes by western blotting. Each lane on the individual blots represents the purified IgG fraction of one horse. The membranes were incubated with monoclonal antibodies to equine $\operatorname{IgGa}, \operatorname{IgGb}, \operatorname{IgGc}$ or $\operatorname{IgG}(\mathrm{T})$.

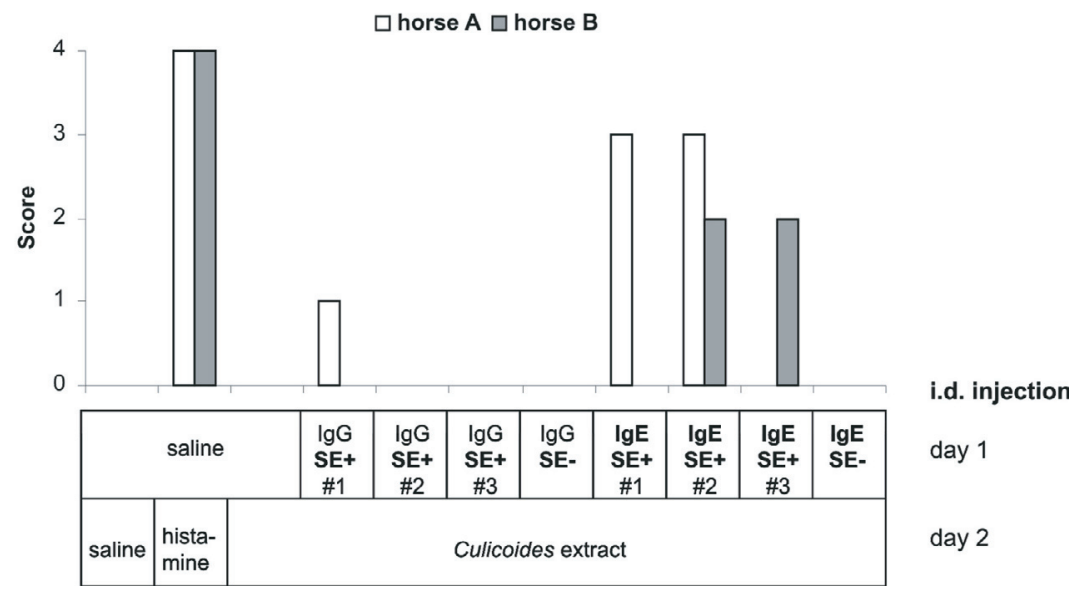

Figure 2. Passive transfer of an immediate skin reaction by intradermal (i.d.) injection of purified serum IgE from allergic horses. Purified IgG and IgE were obtained from three horses affected with summer eczema (SE+ \#1, \#2, \#3) and one healthy animal (SE-). On day $1, \operatorname{IgE}$ and $\operatorname{IgG}$ (composed of $\mathrm{IgGa}, \mathrm{IgGb}$ and $\mathrm{IgGc}$ ) were injected into the skin of two healthy recipient horses (A and B). The next day (day 2), Culicoides extract was injected i.d. at the same locations of the lateral side of the neck. Saline, histamine, or Culicoides extract without previous immunoglobulin injection served as controls. The intensity of the immediate skin reaction was determined 15-20 min after Culicoides allergen injection and in relation to the histamine positive (score 4) and the saline negative controls (score 0 ) of the same horse. 


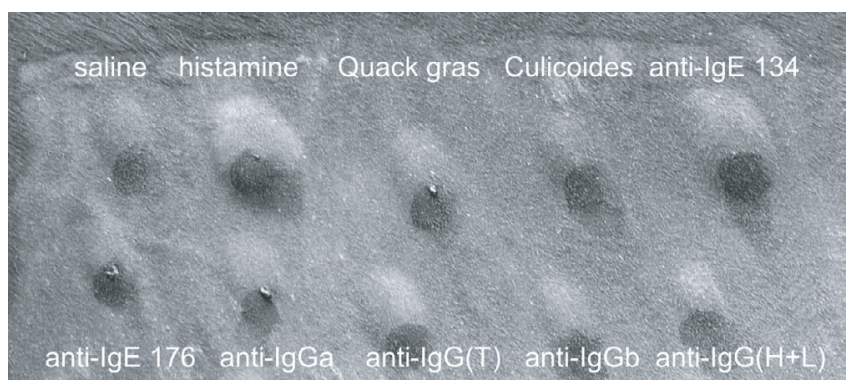

Figure 3. Immediate skin reactions induced by intradermal injection of different anti-equine isotype antibodies. Saline served as a negative, histamine as a positive control. Two allergen preparations (Quack gras and Culicoides), and a polyclonal goat anti-horse $\operatorname{IgG}(\mathrm{H}+\mathrm{L})$ antibody which induced no skin reaction in this horse, were injected as additional controls for skin reactivity. All anti-equine $\mathrm{IgE}$ and $\mathrm{IgG}$ reagents were monoclonal mouse $\mathrm{IgG} 1$ antibodies. The reaction was read $15 \mathrm{~min}$ after i.d. injection and graded from 0 (saline) to 4 (histamine).

was composed of $\mathrm{IgGa}$, IgGb and $\mathrm{IgGc}$, but not $\operatorname{IgG}(\mathrm{T})$. Except for the histamine control, the other two recipient horses did not show any skin reaction regardless of which antibodies were injected the day before. All skin reactions at responsive sites were reduced after $4 \mathrm{~h}$ and had completely disappeared by $24 \mathrm{~h}$.

\subsection{Intradermal injection of anti- equine $\operatorname{IgE}$ and anti-equine $\operatorname{IgG}(\mathrm{T})$ antibodies provoked an immediate skin reaction}

To find more evidence that $\operatorname{IgE}$ is indeed the major antibody causing allergic reactions, antibodies to equine $\mathrm{IgE}$ and various $\mathrm{IgG}$ were injected into the skin of six clinically healthy horses. The immediate skin reaction of one horse in this experiment is shown in Figure 3. All horses showed an immediate skin reaction after injection of anti-IgE134, and 5 out of 6 animals reacted to anti-IgG(T) application (Tab. I). In contrast, after anti-IgGa or anti-IgGb injection only very weak or negative reactions were observed. These results suggested that both $\operatorname{IgE}$ and $\operatorname{IgG}(\mathrm{T})$ are bound to skin mast cells and can cause an immediate allergic reaction in horses. Different results were obtained after i.d. injection of the two antiIgE antibodies. Although anti-IgE134 induced a strong immediate skin reaction in all animals, anti-IgE176 did not.

\subsection{Specificity of the anti-IgE and anti- IgG(T) antibodies}

The specificity of the anti-IgE and anti$\mathrm{IgG}(\mathrm{T})$ antibodies is crucial for the interpretation of skin reactivity induced after i.d. injection of these reagents. To confirm that no cross-reactivity occurred between the anti-IgE antibodies and $\operatorname{IgG}(\mathrm{T})$ or the anti-IgG(T) antibody and equine IgE, various combinations of ELISA testing were performed to detect purified $\mathrm{IgE}$ or $\operatorname{IgG}(\mathrm{T})$ from horse serum. The different combinations of coating and detection antibodies in this test are shown in Figure 4. The assay using anti-IgE176 for coating and anti-IgE134 for detection specifically detected equine $\mathrm{IgE}$, but not $\operatorname{IgG}(\mathrm{T})$. When anti-IgE and anti-IgG(T) antibodies were used in one test, neither IgE nor IgG(T) were recognized. The polyclonal anti-horse $\operatorname{IgG}(\mathrm{H}+\mathrm{L})$ antibody can react with both $\operatorname{IgG}(\mathrm{T})$ and $\operatorname{IgE}$ because of its specificity for immunoglobulin light chains. However, only $\operatorname{IgG}(\mathrm{T})$ could be 
Table I. Individual skin reactivity scores of six horses $15 \mathrm{~min}$ after injection of monoclonal antibodies to horse IgE and IgG.

\begin{tabular}{lcccccccc}
\hline Horse & \multicolumn{2}{c}{ Controls } & & \multicolumn{5}{c}{ Monoclonal antibodies } \\
\cline { 2 - 6 } \cline { 6 - 9 } & saline & histamine & & anti-IgE134 & anti-IgE176 & anti-IgGa & anti-IgGb & anti-IgG(T) \\
\hline 1 & 0 & 4 & & 4 & 0 & 0 & 0 & 3 \\
2 & 0 & 4 & & 3 & 0 & 0 & 0 & 2 \\
3 & 0 & 4 & & 2 & 0 & 0 & 2 & 0 \\
4 & 0 & 4 & & 3 & 0 & 0 & 0 & 3 \\
5 & 0 & 4 & & 3 & 0 & 0 & 0 & 3 \\
6 & 0 & 4 & & 3 & 0 & 0 & 0 & 2 \\
No. of reactions & $0 / 6$ & $\mathbf{6 / 6}$ & & $\mathbf{6 / 6}$ & $0 / 6$ & $0 / 6$ & $1 / 6$ & $\mathbf{5 / 6}$ \\
Median score & 0 & 4 & & 3 & 0 & 0 & 0 & 2.5 \\
\hline
\end{tabular}

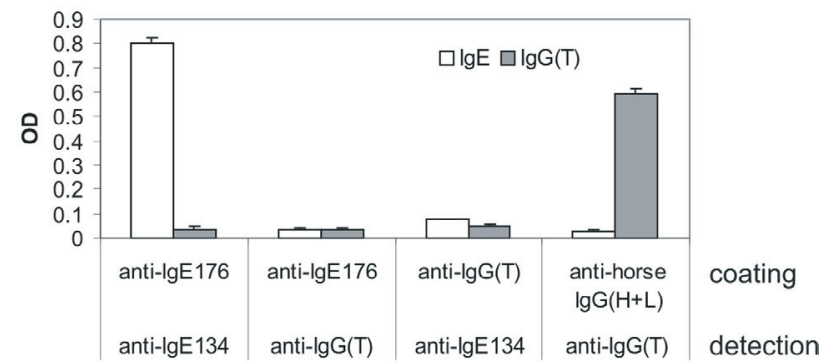

Figure 4. The specificity of monoclonal anti-equine $\operatorname{IgE}$ and anti-equine $\operatorname{IgG}(\mathrm{T})$ antibodies as determined by ELISA. Anti-IgE176, anti-IgG(T) or polyclonal goat anti-horse $\operatorname{IgG}(\mathrm{H}+\mathrm{L})$ antibodies were used for coating. Purified equine $\operatorname{IgE}$ or $\operatorname{IgG}(\mathrm{T})$ was then applied as the test sample. For detection, biotinylated anti-IgE134 or anti- $\operatorname{IgG}(\mathrm{T})$ were used and streptavidin conjugated peroxidase was added in an additional step. The bars represent means and standard deviations of three measurements.

detected by anti-IgG(T) in this test. The ELISA data confirmed the specificity of the anti-IgE and anti-IgG(T) antibodies for $\operatorname{IgE}$ and $\operatorname{IgG}(\mathrm{T})$, respectively. The assay also confirmed that both anti- $\operatorname{IgE}$ antibodies detect soluble IgE.

\subsection{Histamine release from peripheral blood basophils using anti-IgE134 and anti-IgE176}

After i.d. injection, anti-IgE134 induced an immediate skin reaction in all horses, but anti-IgE176 did not provoke any reaction. An additional experiment was performed to explore the differences in the induction of IgE-mediated degranulation by these two reagents. The only cells in peripheral blood containing histamine are basophils. Similar to mast cells, basophils can bind IgE to their cell membranes via FceRI. Crosslinking of the receptor bound $\mathrm{IgE}$ subsequently induces histamine release. Peripheral blood was obtained from four horses with summer eczema and a histamine release assay was performed. The 
Table II. Relative histamine release (\%) from peripheral blood basophils of four horses affected with summer eczema after stimulation with Culicoides extract, anti-IgE134 or anti-IgE176 antibodies.

\begin{tabular}{lccccc}
\hline Histamine release $^{\mathrm{a}}$ & Horse \#1 & Horse \#2 & Horse \#3 & Horse \#4 & Median (min-max) \\
\hline Spontaneous & 7 & 3 & 5 & 5 & $5(3-7)$ \\
Culicoides & 82 & 68 & 83 & 50 & $75(50-83)$ \\
Anti-IgE134 & 57 & 43 & 54 & 51 & $52.5(43-57)$ \\
Anti-IgE176 & 2 & 4 & 3 & 11 & $3.5(2-11)^{\mathrm{b}}$ \\
\hline
\end{tabular}

${ }^{\text {a }}$ The maximal release of each sample was set as $100 \%$. All other samples were described relative to the corresponding maximal release sample.

${ }^{\mathrm{b}}$ The one-sided $p$-value comparing the spontaneous release and the release induced by anti-IgE176 was 0.56 .

amount of free histamine was determined in the supernatants using a competitive radioimmuno assay. Maximal release of histamine was obtained by boiling a sample aliquot. The evaluation was performed setting the maximal release of each sample as $100 \%$ (Tab. II). The spontaneous release, the histamine release induced by Culicoides extract and that induced by anti-IgE antibodies were calculated relative to the corresponding maximal release samples for each horse. Histamine release was induced after incubation of the samples with Culicoides extract and also with anti-IgE134. In contrast, the release of histamine induced by anti-IgE176 was not different from the spontaneous release $(p=$ 0.56 ). The finding that anti-IgE134, but not anti-IgE176, mediated degranulation of blood peripheral basophils was in accordance with the results after i.d. injection of these two antibodies.

\section{DISCUSSION}

The goal of this study was to investigate antibody mediated mechanisms in the skin that contribute to mast cell degranulation and clinical allergy in horses. Skin diseases such as equine summer eczema are believed to be of allergic origin be- cause of typical, seasonal recurrent clinical signs and immediate skin reactions induced by intradermal testing with allergen extracts $[4,13,27]$. By assuming analogy to molecular mechanisms of human allergy and atopic disease, it has been concluded that IgE-mediated mast cell degranulation plays a major role in the pathogenesis of equine summer eczema $[3,19,33]$. However, the direct impact of IgE-mediated mechanisms in the disease had not previously been shown. We performed two in vivo experiments (1) to confirm the causal role of allergen-specific IgE antibodies in the pathogenesis of equine summer eczema and (2) to address the question of whether other immunoglobulin isotypes, such as $\mathrm{IgG}$, are also able to mediate skin mast cell degranulation in horses.

For many decades the classical test to induce allergic reactions in non-allergic individuals has been the Prausnitz-Küstner reaction, first performed in 1921 . Heinz Küstner was allergic to cooked fish and developed an immediate systemic reaction after exposure to it. In the original experiment, the allergic reaction was transferred to Carl Prausnitz by intradermal injection of serum from Küstner, followed by injection of a small quantity of boiled fish extract. The fish extract provoked an immediate wheal-and-flare reaction at the injection 
site of Prausnitz's skin [6]. We performed a modified $\mathrm{P}-\mathrm{K}$ experiment in horses by transferring purified serum $\mathrm{IgE}$ or $\mathrm{IgG}$ fractions, followed by challenge with allergen extract. The experiment showed that the allergic response can be transferred to healthy non-allergic horses using $\operatorname{IgE}$ from affected horses and confirmed the important role of $\mathrm{IgE}$ in the pathogenesis of equine summer eczema.

However, the allergic reaction could only be transferred to two out of four horses by $\operatorname{IgE}$ and not at each injection site of IgE from allergic horses. This could have been caused by a dose-dependent effect and that we were working with the minimal concentration of allergen-specific IgE. Although some attempts have recently been made, the inducing allergen of equine summer eczema is not yet defined [1] and assays to quantify Culicoides-specific IgE antibodies in horse serum are currently not available. Out of the total volume of $100 \mu \mathrm{L}$ that we used per i.d. injection $(50 \mu \mathrm{g} / \mathrm{mL} \operatorname{IgE})$, only a small fraction of the $\operatorname{IgE}$ antibodies was expected to be allergen-specific. Compared to humans, horses have relatively high total serum $\mathrm{IgE}$ concentrations (in the $\mu \mathrm{g} / \mathrm{mL}$ range) and no differences in total serum IgE levels were found between healthy horses and animals affected with summer eczema [30]. Most likely, the majority of IgE antibodies obtained from serum were directed against other antigens, such as parasite antigens, and the concentration of Culicoides-specific IgE in the injected fractions was rather small. Variations in parameters such as the amount of Culicoides-specific $\operatorname{IgE}$ in the purified IgE preparations, the number of mast cells in the injection area of the recipient horses, and the depth of the individual injection sites might have influenced the results. Thus, the amount of Culicoides-specific IgE might just have been sufficient to induce an immediate skin reaction in some but not all recipients after allergen challenge.
In addition to $\mathrm{IgE}$, we tested whether IgG antibodies might be involved in the pathogenesis of equine summer eczema. Equine serum IgG antibodies recognized different proteins from Culicoides extracts by western blotting or proteins in the saliva glands of fixed sections of Culicoides midges by immunohistochemistry [33]. Here, we used purified serum IgG from horses with summer eczema for passive transfer. After Culicoides allergen challenge, immediate skin reactions were not observed in the recipients although the IgG concentration we used $(300 \mu \mathrm{g} / \mathrm{mL})$ was 6-fold higher than that of purified IgE. The only exception was a single weak skin reaction (score 1) which was observed in one recipient animal out of 16 total $\mathrm{IgG}$ injection sites in four horses. The IgG fractions used in the P-K experiment were obtained by Protein $\mathrm{G}$ purification. This procedure selectively enriched certain serum IgG with high-affinity to Protein $\mathrm{G}$, such as $\mathrm{IgGa}, \mathrm{IgGb}$ and $\mathrm{IgGc}$ [25]. Others like $\operatorname{IgG}(\mathrm{T})$ were not bound to the affinity column and were consequently not present in the i.d. injected IgG fraction. The transfer experiment using purified $\mathrm{IgG}$ suggested that neither IgGa, IgGb nor IgGc can mediate skin mast cell degranulation in equine summer eczema.

Injecting monoclonal antibodies to equine $\mathrm{IgE}$ and various $\mathrm{IgG}$ directly into the skin tested whether the corresponding Ig were already bound to skin mast cells via Fc-receptors. In other species, IgE antibodies are bound to the high-affinity FceRI [11]. In humans and rodents, IgG antibodies can also bind to various $\operatorname{IgG}$ receptors $(\mathrm{Fc} \gamma \mathrm{Rs})$ on mast cells and activate or inhibit degranulation depending on the receptor $[7,21,22]$. IgG binding to canine mast cells via Fc $\gamma$-receptors has also been reported [23]. In our experiments using six healthy horses, an immediate skin reaction was induced in all horses by anti-IgE134 and in five out of six horses by the anti-IgG(T) antibody CVS40. At 
15 min after i.d. injection, the immediate skin reaction induced by anti-IgG(T) was also slightly lower (median score 2.5) than the reactivity induced by anti-IgE134 (median score 3). This was similar to human mast cells that showed decreased IgG-dependent degranulation compared to degranulation mediated by IgE [32].

Equine $\operatorname{IgG}(\mathrm{T})$ must have already been bound to Fc-receptors on mast cells to induce an immediate skin reaction after anti-IgG(T) injection. The observation that skin mast cells were already sensitized by $\mathrm{IgG}(\mathrm{T})$ suggests that free $\operatorname{IgG}(\mathrm{T})$ antibodies can bind to high-affinity Fc $\gamma$-receptors on equine skin mast cells and that these Fc $\gamma$-receptors can activate cellular degranulation. This is similar to the interaction of $\mathrm{IgG}$ and the high-affinity Fc $\gamma \mathrm{RI}$ on human mast cells [21] and differs from binding of IgG to low affinity Fc $\gamma$ RII and Fc $\gamma$ RIII that requires prior IgG/allergen complex formation [22]. Equine $\operatorname{IgG(T)}$ is not an isotype; rather, it represents a fraction of equine IgG composed of IgG3 and IgG5 [31]. The anti-IgG(T) antibody CVS40 recognizes both isotypes, although it seems to have a higher affinity to $\mathrm{IgG} 5^{2}$. We do not yet know whether skin mast cell sensitization and immediate skin reactivity was mediated by $\mathrm{IgG} 3$ or IgG5 or by both isotypes.

After i.d. injection of the two anti-IgE mabs, only anti-IgE134 induced an immediate skin reaction, but not anti-IgE176. The potential of both anti-IgE mabs to induce degranulation via $\operatorname{IgE}$ bound to Fce-receptors was tested using a histamine release assay on a different cell population, namely peripheral blood cells. This assay targeted basophils which also express the high-affinity FceRI and are the only cells in the peripheral blood containing histamine [18]. Histamine release from peripheral blood basophils was induced by anti-IgE134, but not by anti-IgE176 anti-

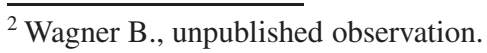

body, which is consistent with the intradermal skin testing result indicating degranulation from mast cells.

Previous studies demonstrated that these two antibodies detect cell bound IgE on peripheral blood cells equally by flow cytometric analysis. In contrast, they recognized different epitopes on the equine IgE heavy chain constant region by SDS-PAGE and western blotting. Anti-IgE134 detected a conformational epitope under non-reducing conditions which was destroyed after treatment of IgE with reducing substances. The IgE heavy chain epitope recognized by anti-IgE176 was still detectable under reducing conditions. This suggested that anti-IgE176 recognizes a linear epitope [30].

A key event in mast cell and basophil degranulation is the cross-linking of the IgE/FceRI complex. Cross-linking of the receptor via $\operatorname{IgE}$ antibodies initiates signaling through the FceRI and subsequently results in cellular degranulation [11]. Although both antibodies can bind to FceRI bound $\operatorname{IgE}$, we conclude that anti-IgE176 did not cross-link the IgE/FceRI complex. Consequently, degranulation was not induced by the anti-IgE176 antibody. Both anti-IgE antibodies are useful tools for continuing investigations on the molecular mechanisms of IgE-mediated allergic diseases in the horse. The monoclonal antiIgE176 might also be a potential candidate for in vivo applications and treatment of allergic conditions, because of its lack in mediating degranulation in sensitized mast cells and basophils.

In summary, our experiments using transfer of $\operatorname{IgE}$ from allergic animals and intradermal injection of anti-IgE antibodies provide strong evidence that IgE mediates mast cell degranulation and allergy in horses. The modified Prausnitz-Küstner experiment also resulted in the first direct evidence that Culicoides-specific IgE antibodies contribute to the pathogenesis of equine summer eczema. Intradermal 
injection of monoclonal antibodies indicate that $\operatorname{IgG}(\mathrm{T})$ can also activate skin mast cells and might have a potential role in allergic conditions of the horse.

\section{ACKNOWLEDGEMENTS}

This work was supported by the Harry M. Zweig Memorial Fund for Equine Research.

\section{REFERENCES}

[1] Althaus H., Muller N., Busato A., Mellor P.S., Torsteinsdottir S., Marti E., Cloning and sequencing of a cDNA expressing a ribosomal P0 peptide from Culicoides nubeculosus (Diptera), Vet. Immunol. Immunopathol. 99 (2004) 99-111.

[2] Anderson G.S., Belton P., Kleider N., Hypersensitivity of horses in British Columbia to extracts of native and exotic species of Culicoides (Diptera: Ceratopogonidae), J. Med. Entomol. 30 (1993) 657-663.

[3] Anderson G.S., Belton P., Jahren E., Lange H., Kleider N., Immunotherapy trial for horses in British Columbia with Culicoides (Diptera: Ceratopogonidae) hypersensitivity, J. Med. Entomol. 33 (1996) 458-466.

[4] Braverman Y., Preferred landing sites of Culicoides species (Diptera: Ceratopogonidae) on a horse in Israel and its relevance to summer seasonal recurrent dermatitis (sweet itch), Equine Vet. J. 20 (1988) 426-429.

[5] Brostrom H., Larsson A., Troedsson M., Allergic dermatitis (sweet itch) of Icelandic horses in Sweden: an epidemiological study, Equine Vet. J. 19 (1987) 229-236.

[6] Cohen S.G., Zelaya-Quesada M., Prausnitz and Küstner phenomenon: the P-K reaction, J. Allergy Clin. Immunol. 114 (2004) 705710.

[7] Daeron M., Fc receptor biology, Annu. Rev. Immunol. 15 (1997) 203-234.

[8] Greiner E.C., Fadok V.A., Rabin E.B., Equine Culicoides hypersensitivity in Florida: biting midges aspirated from horses, Med. Vet. Entomol. 4 (1990) 375-381.

[9] Greiner E.C., Entomologic evaluation of insect hypersensitivity in horses, Vet. Clin. North Am. Equine Pract. 11 (1995) 29-41.
[10] Halldordsottir S., Larsen H.J., An epidemiological study of summer eczema in Icelandic horses in Norway, Equine Vet. J. 23 (1991) 296-299.

[11] Kinet J.P., The high-affinity IgE receptor (FceRI): from physiology to pathology, Annu. Rev. Immunol. 17 (1999) 931-972.

[12] Lange S., Hamann H., Deegen E., Ohnesorge B., Distl O., Investigation of the prevalence of summer eczema in Icelandic horses in northern Germany, Berl. Munch. Tierarztl. Wochenschr. 118 (2005) 481-489.

[13] Larsen H.J., Bakke S.H., Mehl R., Intradermal challenge of Icelandic horses in Norway and Iceland with extracts of Culicoides spp., Acta Vet. Scand. 29 (1988) 311-314.

[14] Lebis C., Bourdeau P., Marzin-Keller F., Intradermal skin tests in equine dermatology: a study of 83 horses, Equine Vet. J. 34 (2002) 666-671.

[15] Littlewood J.D., Incidence of recurrent seasonal pruritus ("sweet itch") in British and German shire horses, Vet. Res. 142 (1998) 66-67.

[16] Lunn D.P., Holmes M.A., Antczak D.F., Agerwal N., Baker J., Bendali-Ahcene S., Blanchard-Channell M., Byrne K.M., Cannizzo K., Davis W., Hamilton M.J., Hannant D., Kondo T., Kydd J.H., Monier M.C., Moore P.F., O’Neil T., Schram B.R., Sheoran A., Stott J.L., Sugiura T., Vagnoni K.E., Report of the Second Equine Leukocyte Antigen Workshop, Squaw valley, California, July 1995, Vet. Immunol. Immunopathol. 62 (1998) 101-143.

[17] Mansfield J.R., Burrell M.H., Curl V.J., Valler B.J., Treatment of equine allergic diseases with allergy neutralization. A field study, J. Nutr. Environ. Med. 8 (1998) 329_ 334.

[18] Marone G., Casolaro V., Patella V., Florio G., Triggiani M., Molecular and cellular biology of mast cells and basophils, Int. Arch. Allergy Immunol. 114 (1997) 207-217.

[19] Matthews A.G., Imlah P., McPherson E.A., A reagin-like antibody in horse serum: 1 . Occurrence and some biological properties, Vet. Res. Commun. 6 (1983) 13-23.

[20] McGorum B.C., Dixon P.M., Halliwell R.E.W., Quantification of histamine in plasma and pulmonary fluids from horses with chronic obstructive pulmonary disease, before and after "natural (hay and straw) challenges", Vet. Immunol. Immunopathol. 36 (1993) 223-237. 
[21] Okayama Y., Kirshenbaum A.S., Metcalfe D.D., Expression of a functional highaffinity $\mathrm{IgG}$ receptor, $\mathrm{Fc} \gamma \mathrm{RI}$, on human mast cells: up-regulation by IFN- $\gamma$, J. Immunol. 164 (2000) 4332-4339.

[22] Ravetch J.V., Bolland S., IgG Fc receptors, Annu. Rev. Immunol. 19 (2001) 275-290.

[23] Sato Y., Teshima R., Nakamura R., Takagi K., Sasaki N., Sawada J., Kitani S., Canine mast cell activation via human IgG1 and IgG4, Int. Arch. Allergy Immunol. 135 (2004) 154-160.

[24] Schmallenbach K.H., Rahman I., Sasse H.H.L., Dixon P.M., Halliwell R.E.W., McGorum B.C., Crameri R., Miller H.R.P., Studies on pulmonary and systemic Aspergillus fumigatus-specific $\mathrm{IgE}$ and $\mathrm{IgG}$ antibodies in horses affected with chronic obstructive pulmonary disease (COPD), Vet. Immunol. Immunopathol. 66 (1998) 245-256.

[25] Sheoran A.S., Holmes M.A., Separation of equine $\mathrm{IgG}$ subclasses (IgGa, IgGb and $\operatorname{IgG}(\mathrm{T})$ ) using their different binding characteristics for staphylococcal protein A and streptococcal protein G, Vet. Immunol. Immunopathol. 55 (1996) 33-43.

[26] Sheoran A.S., Lunn D.P., Holmes M.A., Monoclonal antibodies to subclassspecific antigenic determinants on equine immunoglobulin gamma chains and their characterization, Vet. Immunol. Immunopathol. 62 (1998) 153-165.
[27] Ungar-Waron H., Braverman Y., Gluckman A., Trainin Z., Immunogenicity and allergenicity of Culicoides imicola (Diptera: Ceratopogonidae) extracts, J. Vet. Med. B 37 (1990) 64-72.

[28] Wagner B., Radbruch A., Richards C., Leibold W., Monoclonal equine $\operatorname{IgM}$ and IgG immunoglobulins, Vet. Immunol. Immunopathol. 47 (1995) 1-12.

[29] Wagner B., Siebenkotten G., Leibold W., Radbruch A., Expression of a 4-(Hydroxy3-nitro-phenyl) acetyl (NP) specific equimurine $\operatorname{IgE}$ antibody that mediates histamine release in vitro and a Type-I skin reaction in vivo, Equine Vet. J. 34 (2002) 657-665.

[30] Wagner B., Radbruch A., Rohwer J., Leibold W., Monoclonal anti-equine IgE antibodies with specificity for different epitopes on the immunoglobulin heavy chain of native $\operatorname{IgE}$, Vet. Immunol. Immunopathol. 92 (2003) 45-60.

[31] Wagner B., Immunoglobulins and immunoglobulin genes of the horse, Dev. Comp. Immunol. 30 (2006) 155-164.

[32] Woolhiser M.R., Okayama Y., Gilfillan A.M., Metcalfe D.D., IgG-dependent activation of human mast cells following upregulation of FcgammaRI by IFN-gamma, Eur. J. Immunol. 31 (2001) 3298-3307.

[33] Wilson A.D., Harwood L.J., Bjornsdottir S., Marti E., Day M.J., Detection of IgG and IgE serum antibodies to Culicoides salivary gland antigens in horses with insect dermal hypersensitivity (sweet itch), Equine Vet. J. 33 (2001) 707-713. 